\title{
"Slowing" and "Narrowing" the Flow of Metals for Consumer Goods: Evaluating Opportunities and Barriers
}

\author{
Elsa Dominish ${ }^{1}$, Monique Retamal ${ }^{1}$, Samantha Sharpe ${ }^{1}$, Ruth Lane ${ }^{2}$ (1), \\ Muhammad Akbar Rhamdhani ${ }^{3}$ (D), Glen Corder ${ }^{4}$, Damien Giurco ${ }^{1}$ (i) and Nick Florin ${ }^{1, *}$ \\ 1 Institute for Sustainable Futures, University of Technology Sydney, Ultimo, NSW 2007, Australia; \\ elsa.dominish@uts.edu.au (E.D.); Monique.Retamal@uts.edu.au (M.R.); samantha.sharpe@uts.edu.au (S.S.); \\ damien.giurco@uts.edu.au (D.G.) \\ 2 School of Social Sciences, Monash University, Clayton, VIC 3800, Australia; ruth.lane@monash.edu \\ 3 Mechanical and Product Design Engineering, Swinburne University of Technology, Hawthorn, VIC 3122, \\ Australia; ARhamdhani@swin.edu.au \\ 4 Sustainable Minerals Institute, The University of Queensland, Brisbane, QLD 4072, Australia; \\ g.corder@smi.uq.edu.au \\ * Correspondence: nick.florin@uts.edu.au
}

Received: 22 December 2017; Accepted: 28 March 2018; Published: 5 April 2018

\begin{abstract}
Metal resources are essential materials for many consumer products, including vehicles and a wide array of electrical and electronic goods. These metal resources often cause adverse social and environmental impacts from their extraction, supply and disposal, and it is therefore important to increase the sustainability of their production and use. A broad range of strategies and actions to improve the sustainability of resources are increasingly being discussed within the evolving concept of the circular economy. This paper uses this lens to evaluate the opportunities and barriers to improve the sustainability of metals in consumer products in Australia, with a focus on strategies that "slow" and "narrow" material flow loops. We have drawn on Allwood's characterisation of material efficiency strategies, as they have the potential to reduce the total demand for metals. These strategies target the distribution, sale, and use of products, which have received less research attention compared to the sustainability of mining, production, and recycling, yet it is vitally important for changing patterns of consumption in a circular economy. Specifically, we have considered the strategies of product longevity (life extension, intensity of use, repair, and resale), remanufacturing, component reuse, and using less material for the same product or service (digitisation, servicisation, and light-weighting). Within the Australian context, this paper identifies the strategies that have the greatest opportunity to increase material efficiency for metal-containing products (such as mobility, household appliances, and personal electronics), by evaluating current implementation of these strategies and identifying the material, economic, and social barriers to and opportunities for expanding these strategies. We find that many of these strategies have been successfully implemented for mobility, while applying these strategies to personal electronics remains the biggest challenge. Product longevity emerged as the strategy with the most significant opportunity for further implementation in Australia, as it is the most broadly applicable across product types and has significant potential for material efficiency benefits. The barriers to material efficiency strategies highlight the need for policies that broaden the focus beyond closing the loop to "slowing" and "narrowing" material loops.
\end{abstract}

Keywords: circular economy; metals; material efficiency; product longevity; remanufacturing; servicisation 


\section{Introduction}

\subsection{The Circular Economy Approach to Sustainability for the Minerals Sector}

The metals sector has an important role to play in driving sustainable development, particularly in supplying the resources needed for low-carbon climate resilient infrastructure [1]. However, at the same time, it must ensure an adequate supply of resources and address the often significant adverse social and environmental impacts of supply chains [2]. The concept of a circular economy for metals has emerged as a refreshed framework for sustainability in the metals sector [3]. The circular economy can be described as: "a regenerative system in which resource input and waste, emission and energy leakage are minimised by slowing, closing, and narrowing material and energy loops" [4].

These concepts are not new and build upon other conceptual frameworks focused on circulating resources, such as the lake or performance economy [5,6], cradle-to-cradle [7], and industrial ecology (e.g., [8,9]). The recent conception of the circular economy has drawn upon these established disciplines to revive and popularise the concept, particularly within the commercial sector [10-12]. We interpret "slowing" as increasing product lifetimes, use-intensity, and dematerialisation "closing" as recycling or diverting resources from waste, and "narrowing" as reducing resource and energy use whilst maintaining product functionality or service.

The circular economy concept is particularly applicable to the metals sector as these materials are typically durable, readily recyclable, and retain their properties over many uses [3]. At the same time, reuse and recycling rates are well below what is possible [13,14], and approximately $50 \%$ of the metals consumed in Australia become waste [15].

Although there are emerging critiques that advise caution in adopting the concept of a circular economy as an analogue for sustainable development (see [16]), we argue that it is a useful concept if based on the broader definition of Geissdoerfer et al. [4]. Specifically, a focus on "slowing" and "narrowing", alongside closing material and energy loops, implies the need to reduce total demand. This suggests the need for significant socio-technical system change and acknowledges that there are limits to growth - a concept that is underemphasized in other sustainability frameworks for this sector. Furthermore, the growing interest in the circular economy creates a leverage point to engage industry, governments, and consumers in material and energy efficiency.

\subsection{A Need to Focus on Metals and Minerals throughout the Product Cycle}

The sustainability of the metals and minerals sector often focuses on the impacts of mining and processing, or at end-of-life $[17,18]$. The circular economy concept theoretically expands the focus to the sustainability of metals throughout their entire lifecycle, including in product design, distribution, sales, and use phases. However, much of the current research on metals in the circular economy is focused on industrial recycling, with the focus largely oriented towards the logistical challenges of collection and the technical and thermodynamic limits of metals recycling (see for example $[15,19,20]$ ). This is especially true in the context of Australia, where the metals industry is mostly active at either end of the product lifecycle (i.e., the mining or recycling of materials) [21]. This has been the focus as mining plays a significant role in the Australian economy, in particular during the recent mining boom (2003-2014), and because there is a limited manufacturing sector for metal-containing products and a small domestic market [22]. With Australia's history as a resource-extractive economy, and the subsequent downturn, there is a greater need for Australia to focus on the use of metals in other parts of the product cycle, such as the distribution, sales, and use phases.

\subsection{A Need for Circular Economy Strategies That Reduce Total Demand}

Allwood et al. [23] set out a typology of strategies for material and energy efficiency, and highlight that only the material efficiency strategies can reduce total demand [16]. These strategies tend to focus on product design, distribution, sales, and use phases of the product cycle, and on changing behaviours and business practices, rather than on resource extraction and recycling. In this study, we focus on 
consumer products, such as cars, electrical and electronic appliances, and other miscellaneous items such as toys and bikes, many of which contain large amounts of bulk and high-value specialty metals [20]. Recovering the materials contained within electronic devices has become particularly important due to their valuable metal content, their relatively short lifecycle, and the rapid growth in use [15].

Further justification for this focus is the recognition that while recycling is vitally important, there are theoretical and practical limitations to the concept of closing the loop. Even when closed, material loops are pushed towards thermodynamic limitations and new material inputs are required to offset cycle losses and meet new demand [23,24]. In the specific case of metals, Graedel et al. [14], in estimating the recycling efficiency for specific metals (as a proxy for the extent of circularity), point to the often significant lag between when materials are first put into use and when they become available for recycling, which limits the potential of recycling to offset a stable demand. Their estimations of the flow of metallic elements along the supply chain also demonstrates the not insubstantial quantities that are 'lost by design' [25]. While closing the material loop by recycling leads to energy savings, compared to primary production, new energy inputs are also required to collect, transport, recycle, and remanufacture goods [26]. While there is value in strategies focused on closing the loop, for a sustainable circular economy, we also need to enable strategies that reduce total demand, by also "slowing and narrowing" material and energy loops.

In this paper, we draw on Allwood et al.'s [23] typology regarding material efficiency strategies to examine strategies implemented in Australia for metal-containing consumer products. We begin by outlining our analytical framework and scope, and then evaluate the implementation of the strategies for metal-bearing products in Australia, drawing on examples identified through industry engagement and literature review. We then examine the major barriers (including material, economic, and social) to their implementation and identify the key opportunities for expanding the strategies beyond their current implementation. While we use examples from Australia, many of the findings are broadly applicable to other industrialised countries; however, many of the issues discussed are heightened in Australia as a resource-extractive economy.

\section{Analytical Framework and Methods}

In this paper, we draw on the material efficiency strategies set out by Allwood et al. [23] (see Table 1) to investigate the potential for circular economy activities for metals in Australia. In Table 1, we set out these four strategies and align them with the key actions of the circular economy according to Geissdoerfer et al. [4]. These strategies differ from the traditional focus on metals recycling and "closing" the loop, and instead focus on other aspects of circularity which involve "slowing" and "narrowing" the flows of metals.

Table 1. Material efficiency strategies aligned with circular economy actions (after Allwood et al. [23]).

\begin{tabular}{|c|c|c|c|}
\hline & Strategies & Description & $\begin{array}{l}\text { Relation to Geissdoerfer et al. [4] } \\
\text { Definition of Circular Economy }\end{array}$ \\
\hline \multirow{4}{*}{ 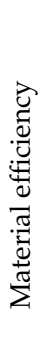 } & Product longevity & $\begin{array}{l}\text { Strategies to increase product lifetimes, } \\
\text { intensify use, and enable repair and reuse }\end{array}$ & Slowing \\
\hline & Remanufacturing & $\begin{array}{l}\text { Material or product life extension by design for } \\
\text { upgrade or remanufacturing }\end{array}$ & Narrowing \\
\hline & Component reuse & $\begin{array}{l}\text { Reusing durable components within new } \\
\text { products (component-oriented) }\end{array}$ & Narrowing \\
\hline & $\begin{array}{l}\text { Using less material to } \\
\text { provide the same } \\
\text { product or service }\end{array}$ & $\begin{array}{l}\text { Strategies to reduce material use through } \\
\text { digitisation, servicisation, and lightweighting }\end{array}$ & Narrowing \\
\hline
\end{tabular}

We have mapped these material efficiency strategies to their most important applications in the existing metal supply chain in Table 2 . This highlights that these strategies apply across various phases 
of the product cycle, except for extraction and production. This is in contrast to recycling, which focuses more on the end of product life. These material efficiency strategies can extend the longevity of metals in use, and there are opportunities to increase material use intensity, or eliminate material use entirely, and minimise additional energy inputs.

Table 2. Mapping material efficiency strategies to metal-containing product supply chains.

\begin{tabular}{|c|c|c|c|c|c|c|c|c|}
\hline \multirow{2}{*}{$\begin{array}{l}\text { Main Points of } \\
\text { Intervention in } \\
\text { Value Chain }\end{array}$} & \multicolumn{3}{|c|}{ Product Longevity } & \multirow[t]{2}{*}{$\begin{array}{l}\text { Remanu- } \\
\text { facturing }\end{array}$} & \multirow[t]{2}{*}{$\begin{array}{l}\text { Component } \\
\text { Reuse }\end{array}$} & \multicolumn{3}{|c|}{$\begin{array}{l}\text { Using Less Material to Provide } \\
\text { the Same Product or Service }\end{array}$} \\
\hline & $\begin{array}{c}\text { Life } \\
\text { Extension }\end{array}$ & $\begin{array}{l}\text { Intensity } \\
\text { of Use }\end{array}$ & $\begin{array}{l}\text { Repair and } \\
\text { Resale }\end{array}$ & & & Digitisation & Servicisation & $\begin{array}{c}\text { Light- } \\
\text { Weighting }\end{array}$ \\
\hline $\begin{array}{l}\text { Extraction } \\
\text { Production }\end{array}$ & & & & & & & & \\
\hline $\begin{array}{l}\text { Design and } \\
\text { Manufacturing }\end{array}$ & $x$ & & $x$ & $\mathrm{x}$ & $x$ & $x$ & & $x$ \\
\hline Retail & $x$ & $x$ & $\mathrm{x}$ & $x$ & & $x$ & $x$ & \\
\hline Use & $x$ & $x$ & & & & $x$ & $x$ & \\
\hline End of first life & & & $x$ & $x$ & $x$ & & & \\
\hline
\end{tabular}

In the following section, we explore each of Allwood et al.'s [23] material efficiency strategies, and how they have been implemented for metal-bearing consumer products in Australia, classified broadly as mobility (e.g., cars, bicycles), household appliances (e.g., whitegoods, televisions), and personal electronics (e.g., mobile phones, laptops). We have analysed the material efficiency strategies by product categories, in order to enable a consistent comparison across the strategies. Drawing on literature and industry engagement, we discuss the degree to which they deliver a reduction in total demand. By identifying examples of current implementations across each product category, and considering the potential material, economic, and social barriers limiting new implementations, we evaluate future opportunities. Based on this qualitative assessment, we have identified the strategies that have the clearest potential for material efficiency benefits with the broadest applicability across different product types, also highlighting opportunities for policy intervention and new business models.

\section{Results: Opportunities for and Barriers to Material Efficiency Strategies}

\subsection{Product Longevity}

\subsubsection{Opportunities}

Product longevity refers to a range of strategies that can contribute to moderating demand for new products by keeping existing products in use. There are three main opportunities according to Allwood et al. [23]: extending product-lifetimes; increasing the intensity of product use; and repairing and reusing goods. We discuss each of these in turn with regard to consumer products, such as vehicles, major appliances, and personal electronic devices. When considering the suitability of various strategies for different product types, a study by Cox et al. [27] provides a useful typology. From their research in the UK investigating consumer expectations of product lifetimes, Cox et al. [27] identified three categories of products: "workhorses" such as major electrical appliances that are expected to last a long time (7-10 years); "up-to-date" products such as personal electronics, which had the shortest expected lifetimes (between 0-2 or 3-4 years); and "investment" products thatwere seen as quality items in which people invest and take extra care [27]. Based on the typology by Cox et al. [27], consumers are likely to be more interested in strategies for product longevity for "workhorses" or "investment" items. However, this does not reflect which products need to last longer from an environmental perspective. 


\section{Product-Life Extension}

Extending the life of products increases the material efficiency of the metals contained without the need for additional energy, as would be required for recycling. This is a particularly useful strategy for products for which the environmental impact of the production phase product is relatively high. The trend of shortening lifespans of products over time is due to the behaviours of both producers and consumers: producers aim to sell more products; consumers may desire new products and replace them before they stop working; and technological (but not material) obsolescence may also force consumers to purchase a new product sooner [27], such as when new software ceases to function on older electronic devices. In the latter case, both the physical and technological life of products need to be considered.

If we consider the categories of products identified by Cox et al. [27] for the metal-containing consumer products we consider in this paper, vehicles and major household appliances are likely to fit in the "workhorse" category, where consumers have high expectations for product lifespans. Some vehicles may also fit into the "investment" category. This would suggest that consumers would see benefit in extending the lifetimes of major household appliances and vehicles. In 2011, Australian Consumer Law was enacted and introduced consumer guarantees, which increased the requirements for producers to provide and repair goods so that they are "safe, lasting and with no faults" [28]. This law is intended to protect consumers from faulty or unreasonably short product lifetimes and could encourage retailers to shift towards selling more durable, reliable goods. However, the length of time for which this new consumer guarantee should last, or how long a reasonable product lifetime should be, is subject to the opinion of the seller and, ultimately, the courts. Aside from this legislation, there are a lack of government or commercially driven attempts in Australia to increase product lifetimes.

Vehicles ceased to be manufactured in Australia in 2017 [29], and the last refrigerator was made in Australia in 2016 [30]. Manufacturing is currently diminishing in Australia, and there are consequently limited opportunities for Australian innovations in production. Therefore, it may be more appropriate for the Australian government to set standards for longevity on imported goods. However, the regulatory focus in Australia has been on the operational impacts of appliances, rather than on product longevity. The performance standards and labelling of major household appliances in Australia typically relate to energy or water consumption during use (e.g., Minimum Energy Performance Standards (MEPS) and the Water Efficiency Labelling and Standards (WELS) scheme [31]). For example, the Australian Design Rules for vehicles, set out under the Motor Vehicle Standards Act of 1989 focus on issues such as safety, vehicle emissions, and anti-theft mechanisms [32]. Under these design rules, there may be opportunities to create standards for product longevity and reusability or recyclability.

For consumer products with short lifespans such as personal electronics, the majority of the environmental impact occurs in the production phase, so while consumers have low expectations for their lifespans, from an environmental perspective, there is a strong case for extending the product lifespan. As products are designed to be more energy efficient in the use phase, the environmental impact of the production phase increases. For example, for the iPhone 3, the carbon footprint of the use phase (49\%) was similar to the production phase (45\%) [33]. However, this ratio shifted significantly with the iPhone $6 \mathrm{~s}$, which is estimated to create $84 \%$ of its carbon footprint during production and $10 \%$ during use, in addition to increasing its overall footprint [34]. Research by the Australia Mobile Telecommunications Association found that between 2010 and 2014, the desire for new technology was the major reason for replacing a phone with the introduction of smartphones [35]. However, as the rate of technological development has slowed, more people are starting to keep their phone for two years or more, and poor performance of mobile phones is now the major reason for replacing a mobile phone, indicating that extending the product life of mobile phones would have significant benefit [35]. Rethinking the design of mobile phones and developing phones that are customizable to a user's requirements promotes longer use times, as they can be upgraded or repaired more easily and personalized so the user develops an attachment to the use. There are now several organisations developing this idea, including "Fairphone", which makes a modular, upgradeable phone and has 
plans to develop their phone as a service [36]. However, these types of customizable mobile phones are not yet available in Australia.

Increase Intensity of Use

For products that remain idle or underutilized for large parts of their product life, material efficiency can be increased through increasing the intensity of use. New business models that facilitate asset sharing are emerging in the 'sharing economy', with the advent of internet-based platforms to enable online booking and payment for use [37,38]. This phenomenon has strong links to product-service systems (PSS), where businesses combine products and services to deliver an outcome, so that the consumer pays for a service or access to a product $[39,40]$. For business-to-consumer applications, intensifying product use through sharing of metal-containing products is most common for vehicles and bicycles, through bike-share, car-share, ride-share, and taxi-share.

Carsharing can have an environmental benefit for materials if using the service results in less car ownership and an energy and emissions benefit if it reduces car use. Three types of carsharing are described below: (1) Sharing of new assets owned by a business, which leads to fewer new cars purchased (by the business instead of privately); (2) Sharing of existing assets owned privately, which leads to no new cars purchased; and (3) Sharing of existing trips (ridesharing or taxisharing), which leads to a potential decrease in trips and a decrease in cars purchased. An independent survey of members of "GoGet", Australia's largest carsharing organisation (type 1) found that more than 60\% of members had deferred the purchase of a private car since becoming a member [41]. Other studies in theUnited States have shown that for each car-sharing car on the road, between 9 and 13 cars are taken off the road [42]. Other business models are emerging in Australia, such as "Car Next Door", where the public can list their own car as available for use during times that it is unused (type 2), thereby reducing the purchase of new cars. Smartphones and GPS technology are enabling real-time ridesharing, which matches drivers with riders as the trip takes place [43] (type 3). However, presently in Australia, ridesharing or carpooling apps such as "CoSeats" or "ShareUrRide" tend to offer longer-distance intercity trips [44,45], rather than commuting options. The taxi-sharing component of Uber-Uberpool-is not yet available in Australia [46]. The material efficiency benefits of carsharing could be negated in the first type if a company overstocks sharing vehicles and increases the net demand for new vehicles. However, the evidence suggests this has not been the case, and the sharing of existing vehicles or existing rides generally has positive impacts for the environment.

Ridesharing faces limitations to becoming a significant replacement for private car use. Ridesharing can only be a regular transport alternative in certain cases, as it is usually informally coordinated and limited by the need to coordinate schedules between participants [47]. Flexible ridesharing, enabled by ICT, attempts to provide a solution, but it is difficult to achieve the critical mass needed to be successful [48]. During 2017, dockless shared bicycles emerged in Australian cities, with the general public gaining access to bicycles through smartphone applications, such as Ofo, Obike, Mobike, and Reddy Go [49]. These bicycles have sparked controversy due to their scattered placement in public spaces [50]. While shared bicycles can reduce carbon emissions if they replace vehicle trips, the process of competing dockless bicycle companies flooding the streets with bicycles to attain market dominance may create a net increase in consumption of metals. There is some evidence this is the case, with mountains of dockless bicycles being discarded in China due to company bankruptcies [51].

In Australia, rent-to-own schemes or renting for events is more common [52] than periodic short-term rental for electrical and electronic goods, which limits the potential for intensifying use of these items. Major electrical appliances, such as washing machines and dryers, can be shared through communal laundries in apartments, coin-laundries, and laundry services [53]. However, other major household electrical appliances such as televisions and refrigerators may be less shareable due to: convenience/the frequency with which they are used; their immovability; or due to difficulty with transporting or finding space for shared use of goods [54]. Smaller electrical appliances that are used infrequently, such as tools and gardening equipment, can readily be shared through tool libraries 
or through periodic rental. Various tool libraries exist in urban areas around Australia, operating on a membership subscription basis, such as "Toolo" near Sydney or "Brunswick Tool Library" in Melbourne [55,56]; however, they are not widespread [57]. There are also limited peer-to-peer tool renting platforms, such as "ToolMates" and "OpenShed" [58,59]. Companies renting large, expensive, and rarely used tools are far more established and more numerous in Australia. These options for sharing major appliances can intensify use of products, particularly if they enable sharing of existing privately-owned goods. Studies elsewhere have shown up to $90 \%$ reductions in resource use associated with tool rental or tool sharing [60,61]; and 30-90\% reductions in resource use associated with shared laundries or laundry services [62,63]. However, some benefits could be negated if significant transportation of goods is required to enable sharing [64]. All sharing businesses are somewhat limited by the social acceptability of sharing rather than owning goods [40].

\section{Repair and Resale}

With regard to our three categories of products, mobility (vehicles and bicycles) are most commonly repaired in Australia, and the automotive and bicycle repair industries are thriving due to growth in car and bicycle sales [65,66]. Major electrical appliances and personal electronics are much less often repaired. The household appliance repairing industry is in decline in Australia, due to much faster technological change and falling prices for new household appliances [67]. For smaller electrical appliances, such as kettles and toasters, repair services have almost disappeared [67]. Consequently, profits are falling, and fewer people are being employed in the repairing industry for electrical appliances and electronics $[67,68]$. Similarly, for electronic equipment, the low cost of new hardware means that malfunctioning electronics are often replaced rather than repaired, and the electronics repair industry is shrinking [68]. This situation is problematic when we consider that Australia has the highest amount of e-waste in Oceania in both absolute and per-capita terms [69]. The high volume of e-waste generated by Australia and exported to other countries could be significantly reduced by enabling options for repair on-shore and expanding the resale market. The barriers to this are likely to include the low cost of purchasing new items, the high cost of labour in Australia, the growing trend to replace rather than repair [68], the limitations of poor quality goods, and the difficulty of obtaining spare parts [70].

Another major limitation to repairing and reselling is the hoarding behaviours of consumers; there are an estimated 22.5 million mobile phones in storage in Australia [35]. This is close to Australia's population, which is currently 24.8 million people [71]. Further, a survey of electronic products in Australian households in 2015 found that mobile phones and other small electronic devices are likely to be stored for some years after they are no longer used [72], rather than being recycled, repaired, or resold. One in two Australian households are currently storing a fully functional smart phone [72]. As the potential for reuse diminishes during this time in storage owing to obsolescence, measures to recover such products at the end of their first use offer benefits for materials efficiency, as well as capturing further economic value through second-hand trading.

While a large market in second-hand electronics already exists in Australia, much of it is focused on offshore sales to countries unlikely to have systems in place for safe recovery of materials at end of life [72]. The international trade of second-hand electronic goods is legal if the goods are in working order; however, differentiating between goods destined for reuse and those that are waste is problematic, and the scale of the trade of illegal electronic waste is significant [69]. In Australia, a large number of social enterprises, not driven by profit, undertake repair and reuse of electronic equipment. Although these enterprises are not usually profitable and may rely on government funding, they provide training and employment [72,73]. Increasing the practices of repair and second-hand sales in Australia can mitigate and slow the flow of e-waste to other countries. One potential drawback could be where repairing prolongs the life of an inefficient vehicle or appliance. However, given the rapidly shortening lifetimes of electrical and electronic appliances, there is considerable scope to increase lifetimes without causing any significant rebound effects. 


\subsubsection{Barriers to Product Longevity Strategies}

To summarise, the material barriers to product longevity strategies include the limitations of poor quality products, the difficulty of obtaining spare parts for repairs, technological obsolescence, and the limits of shareability, including the frequency of product use and the ability to transport shared goods. For example, vehicles and bicycles may be more readily shared than personal electronic devices, as they are moveable, and less personal in nature. The mode of sharing also matters, as carsharing may work well, while ridesharing may have logistical limitations. Economic barriers to product longevity include the high cost of labour required for repairs and the consequent lack of profitability for repair and resale, as well as potential risks associated with damage to shared goods. Additionally, producers are currently motivated to sell more products rather than engage with or facilitate repair and refurbishment. Social barriers include the trend of replacing rather than repairing goods; a lack of consumer interest in using goods for longer; a lack of acceptability of sharing; desire for new products; and consumers hoarding electronics that are no longer in use. However, hoarding behaviours may be due to the lack of appropriate repairing and reselling options. Business models that enable producers to take back products at their end of life may be a solution to hoarding by consumers.

\subsection{Remanufacturing}

\subsubsection{Opportunities}

The lifespan of a material or product can be extended at the end of its first life, by designing the product so it can be disassembled, remanufactured, and sold, with an equivalent quality to a new product.

The implementation of remanufacturing in Australia has been successful for particular products, but is not yet widespread. There is also a well-established industry for remanufactured vehicle components, such as automatic transmissions and electronic components, which are remanufactured by third-party companies, in collaboration with and certified by the original equipment manufacturers (OEMs) [74-79]. Other examples of remanufactured consumer goods that can be purchased in Australia include household appliances (such as kitchen appliances) and personal electronics (particularly laptop computers), most commonly sold by the OEM [80-82].

There are also examples of rebuilding or refurbishment of products by third-party companies, such as for larger household appliances (e.g., washing machines), but these are not to the same standard as remanufacturing and would be considered repair (see Section 5 on repair and resale). It is unclear how much of remanufactured products sold in Australia are remanufactured locally compared to at an OEM offshore. One of the most well-documented examples of remanufacturing happening domestically is the Sydney-based Fuji-Xerox Eco Manufacturing Centre, which has a range of remanufacturing and recycling initiatives targeting the recovery of end-of-life printing and photocopying equipment, parts and toner cartridges returned by customers for remanufacturing, or third-party processing [21].

There are limitations to both the material and energy savings that can be claimed through remanufacturing, and this is highly dependent on the product design. Savings are firstly from the avoidance of producing new materials and secondly from reduced energy in remanufacturing instead of new manufacturing. Where remanufacturing happens locally, the reduction in transportation can be a further energy saving. However, for products with significant energy consumption in the use phase, remanufacturing older products that are less energy efficient can reduce the potential energy savings from remanufacturing [83]. Remanufacturing makes most sense from an environmental perspective for products at an advanced stage of technology development, where newer model products are unlikely to make significant gains in energy efficiency during the use phase [84]. Otherwise there is the risk that remanufacturing will only extend the life of products that are inefficient and obsolete.

If products are designed for disassembly and remanufacturing, they can deliver much greater savings for materials and energy. A study comparing two Fuji Xerox printers, found that the standard model printer achieved around a $25 \%$ savings of materials, energy, and greenhouse gas emissions 
through remanufacturing. The modular printer, designed for disassembly and remanufacturing, achieved an even greater material saving of $50 \%$ and a $65 \%$ saving for energy and greenhouse gas emissions [85]. Previously, the machines contained more than 80 material types, but over time the head office (based in Japan) has modified the design of the machines to make it easier and quicker to dismantle, with fewer parts to be replaced, making it easier to remanufacture and recycle [21].

\subsubsection{Barriers to Remanufacturing}

The potential for remanufacturing is firstly limited by material factors, such as the original product design, unless products have been designed with remanufacturing in mind [86]. The most suitable products for remanufacturing are those made of durable materials and containing high-value parts [87]. Successful remanufacturing businesses are usually for products that have slow technology development and smaller changes in the product design of new models, such as cars, whitegoods, and office equipment. To expand remanufacturing into industries based on rapidly developing technologies, these products will need to be designed to be upgradable with newer components during the remanufacturing process [85].

The social barriers may be similar to those for repair and resale, where there is a need to match the market for remanufactured products with return flows of products. End-of-life products may be hoarded by consumers and therefore delay the product from being remanufactured and resold, or may be either recycled or disposed of to landfill. This creates a difficulty for remanufacturers to know the timing and quantities of products that will be suitable for remanufacturing [88]. New business models, such as leasing, may provide more certainty for companies, and there are successful examples of businesses adopting this model, such as Fuji Xerox. Consumers' preference for buying new products is also a barrier, with a study finding that the more personal a product, the less likely consumers were to consider purchasing a remanufactured product [89]. Consumers also lack awareness that remanufactured products are available, because remanufactured products are often not sold through regular sales channels [89]. This was found to be true in the case of many Australian products, with remanufactured products usually available only from online websites of OEMs and not in stores. There may be limited quantities of or range in the stock of products, which might not meet customer requirements. The exception to this is remanufactured vehicle parts, which are more widely available and may be offered by mechanics to consumers.

The most significant barriers to remanufacturing are likely to be economic. Most remanufacturing is commercially driven and undertaken by the original manufacturer, where maintaining the business's market share is a larger incentive than the profit of the products themselves [23]. The benefits to businesses can include decreased costs from energy and material savings, increased reliability and performance of products, and new earnings from export of remanufactured products [90]. Manufacturers may perceive they have an economic disincentive to focus on remanufacturing and prefer to prioritise the development of new models of products to stay ahead of technology developments and gain market share [21]. Many manufacturers are resistant to independent companies remanufacturing and reselling their products, and therefore products are often designed to make this practice difficult. In comparing OEMs and independent companies, OEMs have more advantages, including integration with original manufacturing and the relationship with their suppliers and consumers [86]. This provides a barrier in Australia, where there is limited industry in manufacturing on which to build. Based on this, household appliances and mobility (components, rather than vehicles) have fewer barriers to remanufacturing compared to personal electronics.

\subsection{Component Reuse}

If a consumer product can be separated into its component parts and those components can be reused in other products, Allwood et al. [23] refer to this as "non-destructive recycling" or "component reuse", which can enable recycling with minimal energy use and is therefore an environmentally attractive strategy. 


\subsubsection{Opportunities}

Metal components in consumer goods that can be reused in similar or different products include: car parts, such as alloy wheels and panels; toner cartridges; mobile phones; lawnmowers; whitegoods; PC chips reused in toys [83]; and electric motors from tools [91]. The major metals contained in these products are steel and aluminium [83]. An estimate of the potential to reuse steel and aluminium components worldwide is $27 \%$ and $33 \%$, respectively, but little reuse currently occurs [92]. Components that are in good condition at the end of their life could be relocated for use in similar products, such as cars and mobile phones. A production approach to 'design for disassembly' can greatly facilitate component reuse [93]. Components can also be reformed to a new shape that has higher market demand; for example, there is potential for reforming steel sheets from cars, trucks, and smaller products [92].

Despite these opportunities, we are only aware of limited situations in which metal components are reused in Australia for consumer goods. If we consider metal-containing products such as vehicles, household appliances, and personal electronics, the only routine reuse of metal components is for vehicles. Whitegoods (large household appliances) that cannot be sold second-hand in Australia are typically shredded for recycling, with the only "component" that is recovered being refrigerants from air-conditioners and refrigerators [94]. Computers and televisions that are collected under the National Television and Computer Recycling Scheme are usually dismantled and then crushed or shredded for material recycling [95]. Electronic components such as harddrives, batteries, circuit boards, power supplies, and RAM are typically aggregated by recyclers in Australia and sent overseas for further dismantling and recycling [96]. At the second stage of dismantling overseas, some components such as microchips are recovered for reuse, but this is minor [96]. Disassembly of computers for reuse of components is undertaken by some charities and not-for-profit organisations in Australia; however, only a very small volume of the e-waste stream is processed in this way [96]. E-waste streams from the commercial sector represent a viable opportunity for reuse from a recycler's perspective; however, reuse of e-waste from the residential sector is unlikely to be economically viable owing to scale and quality [96].

In contrast to electrical and electronic products, the most common method of recycling motor vehicles in Australia is through component reuse [97]. For younger vehicles, dismantlers typically extract engines, transmissions, radiators, body panels, and alternators for resale and reuse. For older vehicles, parts are extracted depending on demand. For all vehicles, the remaining metal body is shredded and recycled [97]. Reusing vehicle components can have major material efficiency benefits if it reduces demand for production of those parts or if it makes an economic difference in the consumers decision to repair or replace their vehicle.

\subsubsection{Barriers to Component Reuse}

There are a variety of material barriers that may limit component reuse. The lack of standardisation for current design of products means that many components will be incompatible for reuse in the same application [92]. New designs may make components incompatible, or the technology may become obsolete. Components may also be degraded or corroded from previous use and no longer have the required structural qualities, in which case they can only be used for lower-grade applications. Recovering components through reverse logistics is also difficult [83]. Material barriers for e-waste component reuse include the need for recycling companies to physically store recovered components when infrastructure is a significant cost [96].

The prevalence of cheap, imported, new products and expensive local labour in Australia are significant economic barriers. Economic barriers to reusing e-waste components in Australia include the cost of labour in Australia and the falling value of e-waste components. For example, secondand third-generation circuit boards have much lower quantities of valuable metals, and this will limit the recovery value of circuit boards in the future [96]. Economic factors affecting the dismantling of end-of-life vehicles include the cost of transferring the vehicle to a dismantler; the labour, time, 
and ease of dismantling; and the relative cost of new parts [97]. Other future barriers include the declining life expectancy of vehicles and the relatively higher cost of repairing and maintaining older vehicles, rather than buying new [97].

There are fewer social barriers for component reuse, as consumers may be unaware if a small or less-visible part of their product has been reused. However, in terms of vehicle repairs, the demand for second-hand parts largely depends on their social acceptability [97].

\subsection{Using Less Material to Provide the Same Product or Service}

\subsubsection{Opportunities}

The strategy of 'using less material to provide the same product or service' can be realized in three main ways: digitisation can reduce demand for materials by replacing physical goods and services with digital or virtual versions; servicisation replaces physical products with the provision of services; and reducing the amount of material used can also be achieved by making products with less material (i.e., lightweighting). Considering these different approaches, there appears to be significant potential for reductions in material demand and associated positive environmental outcomes. For example, a study commissioned by the Global e-sustainability Initiative (GeSI) estimated that a global reduction of $0.46 \mathrm{GtCO}$ e by 2020 could be achieved through the replacement of carbon-intensive physical products and activities (for example, travel) with alternative services enabled by ICT [98].

\section{Digitisation}

Digitisation, or the digital economy, encompasses a suite of technologies and new IT infrastructure, supporting a broad shift towards online and mobile-enabled media (e.g., away from CDs, DVDs, books). Digitisation facilitates new activities, such as mobile banking, videoconferencing, and telecommuting, and has enabled greater automation of supply chains and the emergence of the Internet of Things (IoT). As an indication of the potential scale of change, the estimated contribution of the new digital economy on Australia's GDP by 2025 is \$A140-250 billion per year [99].

The move away from CDs and DVDs toward digital versions reduces demand for metals (aluminium, silver, gold alloy) that are used in very small quantities for the reflective layer and are typically not recoverable through end-of-life treatment processes [100]. Although digital technology has facilitated the emergence of servicisation and the rental model (discussed below), this is frequently in addition to ownership of a device [101]. There is a trend towards new hybrid products (physical products that can be augmented with services), such as e-books and smartphones, that is changing the way services are delivered; however, these offerings do not negate the purchase of a physical product. In many cases, the physical product simply provides a cross-selling opportunity to deliver additional services to the consumer [101].

The lifecycle of any approach for substituting a product or service with a virtual alternative needs to be carefully considered to ensure that rebound effects are minimised. For example, any shift towards virtual or digital alternatives needs to consider any increases in the use of a service due to ease of access and increases in energy in the use phase (and potential renewable sources for energy), as well as possible new demand for different equipment or tools. Importantly, to classify as a strategy for using less material by digitisation, the alternate version needs to replace a product or activity. Creating digital copies of documents or media in addition to keeping the physical versions does not amount to material savings. Digitisation is likely creating new demand for a suite of tools (smart phones, tablets, and laptops) and the IoT creates new demand for battery-embedded products. According to the Australian Bureau of Statistics (Household Use of Information Technology, Australia 2014-2015) the average household has six devices (including desktop, laptop, mobile or smart phone, and tablet) used to connect to the internet. This growing demand for battery-enabled devices likely significantly offsets the potential for material savings [69]. 


\section{Servicisation}

Certain household products, such as washing machines, dryers, cars, tools, and gardening equipment, appear most suitable for servicisation [54]. In Australia, we find consumer examples in the form of laundry/dry cleaning services, baby nappy services, repair and gardening services, and taxis and ridehailing services. Of these, all are established businesses types in Australia, except for the relatively new ridehailing services available through smartphone apps.

While there is evidence that laundry services can enable significant reductions in material use [62,63], the business-to-consumer market in Australia is modest and has seen a small decline [102]. Households are an important market for dry-cleaning services; however, economic uncertainty and fashion trends away from clothes requiring dry-cleaning is contributing to reduced demand for these services [102]. Market analysis suggests that stricter government regulations around environmental issues and occupational health and safety could impact the structure of the dry-cleaning industry towards a model whereby there are more convenient drop-off points serviced by larger centralized dry-cleaning plants that will be more able to invest in more efficient equipment [102]. These changes might lead to material savings and operational efficiencies; however, a detailed analysis of the transport logistics would be needed to evaluate the whole-of-life impacts.

Servicisation can reduce the resources embodied in the product or equipment, as fewer units are required; however, the operational energy and material consumption will not necessarily be reduced [64]. As discussed above the lifecycle of any approach for substituting a product with a service needs to be carefully considered.

\section{Lightweighting}

Lightweighting can be achieved by designing products/components with less material, material substitution, or adopting more precise manufacturing. Considering the latter, precise manufacturing of components and products can be achieved by 3D printing (additive manufacturing), and this new technology is often flagged as an important strategy for using less materials [103]. We classify this approach as a 'yield efficiency' strategy and therefore out of scope of this review. A key example of using less metal by designing lightweight products and using material substitution is in the automotive industry, where lightweight design is one of the dominant innovations supporting reductions in emissions and fuel demand [104].

Carruth et al. [105] estimated the theoretical potential for savings in steel and aluminium products through lightweighting and suggested an upper limit of 30\% across a wide range of steel- and aluminium-containing products. However, it is important to assess environmental impacts across the whole product lifecycle. Delogu et al. [106] suggest that while mass reduction of steel (e.g., through substitution with advanced high-strength steels) can deliver emission reductions, substitution with wrought aluminium, magnesium, or carbon-fibre reinforced plastic results in greater emissions during material processing [106]. Such differences in the greenhouse gas emissions during production have important implications for electric vehicles, where the emission rate in the use phase is lower compared to internal combustion engine vehicles, potentially limiting the use of innovative materials in this important growth market. Furthermore, material substitutions from metals to hybrid composites are likely problematic for end-of-life processing, requiring advanced recycling technologies to separate fibres from the resin matrix [106]. Any mass reduction strategy achieved by material substitution must consider potentially adverse environmental impacts in the production phase and the implications for material recovery at end-of-life.

\subsubsection{Barriers to Using Less Material to Provide the Same Product or Service}

This strategy has potential for major reductions in material consumption but appears to have significant tradeoffs in terms of rebound effects. There are various material barriers to using less 
material to provide the same product or service. Digitisation offerings can be limited by internet speeds and connectivity, and there are limited household goods that can be replaced by a service.

Economic barriers for this strategy can include the need to shift business models and value offerings from physical products to services. In conjunction, there may be social barriers where consumers may not accept a shift from physical products to services or virtual products. The need for such fundamental socio-technical shifts that potentially undermine or diminish the value of established approaches presents a major barrier.

\section{Discussion}

\subsection{Summary of Opportunities for Different Product Classes}

To evaluate the greatest opportunities to increase material efficiency for consumer products across the four strategies, we reviewed the current implementation, the characteristics of suitable products, and the key material, economic, and social barriers to implementation, summarized in Table 3. In the following section, we highlight the major opportunities for each product type. The suitability of the strategies for specific product classes is most strongly influenced by product design and patterns of use. In our analysis, we have focused on metal-bearing products. The physical characteristics of metals makes them ideally suitable for material efficiency strategies, as they are durable and retain properties through multiple uses. Although many of the strategies, particularly product longevity, increasing intensity of use, and servicisation, may be broadly applicable to other kinds of products, they are important for metal-bearing products owing to the adverse environmental and social impacts of supply.

\subsubsection{Mobility}

Many of the strategies are broadly applicable to mobility (including vehicles, bicycles, and components), with established examples of repair and resale; remanufacturing; reuse of components; and lightweighting already underway in Australia. Australian manufacturers have created a specialised industry in the remanufacturing and reuse of vehicle components. Lightweighting has also been a successful strategy for vehicles, driven by the resulting reductions in fuel demand and emissions. However, lightweighting has the potential to increase emissions in the production phase of the vehicle or to make vehicles less recyclable, and with the shift towards a transportation system based on renewable electricity, there is a need to make sure lightweighting continues to have a positive environmental benefit. Considering that many of these material efficiency strategies are already established for the mobility sector, the greatest new opportunities are in increasing the intensity of use (through carshare and bikeshare) and servicisation, through greater use of ridesharing/carpooling apps. However, these initiatives need to make sure they do not lead to adverse environmental impacts that undermine the potential material efficiency benefits, such as through the creation of additional vehicle trips or through the oversupply of vehicles or bicycles. 
Table 3. Synthesis of opportunities and barriers to material efficiency strategies.

\begin{tabular}{|c|c|c|c|c|c|c|c|c|}
\hline & \multicolumn{3}{|c|}{ Product Longevity } & \multirow[t]{2}{*}{ Remanufacturing } & \multirow[t]{2}{*}{$\begin{array}{l}\text { Component } \\
\text { Reuse }\end{array}$} & \multicolumn{3}{|c|}{ Using Less Material for the Same Product or Service } \\
\hline & Life Extension & Intensity of Use & $\begin{array}{l}\text { Repair and } \\
\text { Resale }\end{array}$ & & & Digitisation & Servicisation & Lightweighting \\
\hline $\begin{array}{l}\text { Implemented examples for } \\
\text { metal-containing products in } \\
\text { Australia }\end{array}$ & $\begin{array}{l}\text { Limited, some } \\
\text { examples in high } \\
\text { quality } \\
\text { mobility/household } \\
\text { appliances }\end{array}$ & $\begin{array}{l}\text { Mobility } \\
\text { (vehicles, } \\
\text { bicycles) }\end{array}$ & $\begin{array}{l}\text { Mobility (vehicles, } \\
\text { bicycles), some } \\
\text { examples of } \\
\text { household } \\
\text { appliances and } \\
\text { personal } \\
\text { electronics }\end{array}$ & $\begin{array}{l}\text { Mobility (vehicle } \\
\text { components), } \\
\text { household } \\
\text { appliances } \\
\text { (high-quality } \\
\text { kitchen } \\
\text { appliances) }\end{array}$ & $\begin{array}{l}\text { Mobility } \\
\text { (vehicles } \\
\text { components) }\end{array}$ & $\begin{array}{l}\text { Limited, } \\
\text { Other (media) }\end{array}$ & $\begin{array}{l}\text { Mobility (taxi } \\
\text { services), household } \\
\text { appliances } \\
\text { (washing machines) }\end{array}$ & $\begin{array}{l}\text { Mobility (mainly } \\
\text { vehicles) }\end{array}$ \\
\hline $\begin{array}{l}\text { Characteristics of applicable } \\
\text { products }\end{array}$ & $\begin{array}{l}\text { Products with } \\
\text { high production } \\
\text { impacts, short } \\
\text { lifespans }\end{array}$ & $\begin{array}{l}\text { Mobile or } \\
\text { infrequently used } \\
\text { products }\end{array}$ & $\begin{array}{l}\text { Products with } \\
\text { high production } \\
\text { impacts, short } \\
\text { lifespans }\end{array}$ & $\begin{array}{l}\text { Durable products, } \\
\text { at advanced stage } \\
\text { of technology } \\
\text { with minimal } \\
\text { changes between } \\
\text { models }\end{array}$ & $\begin{array}{l}\text { Standardized } \\
\text { components, } \\
\text { durable } \\
\text { components }\end{array}$ & $\begin{array}{l}\text { Products with } \\
\text { additional services }\end{array}$ & $\begin{array}{l}\text { Mobile or } \\
\text { infrequently } \\
\text { used } \\
\text { products }\end{array}$ & $\begin{array}{l}\text { Products where } \\
\text { weight impacts } \\
\text { emissions in use }\end{array}$ \\
\hline Likelihood of rebound effects & $\begin{array}{l}\text { Minimal rebound } \\
\text { effects for } \\
\text { products with } \\
\text { short lifetimes }\end{array}$ & $\begin{array}{l}\text { Potential } \\
\text { rebound if } \\
\text { significant } \\
\text { transportation } \\
\text { of goods is } \\
\text { required }\end{array}$ & $\begin{array}{l}\text { Minimal rebound } \\
\text { effects for } \\
\text { products with } \\
\text { short lifetimes }\end{array}$ & $\begin{array}{l}\text { Risk of rebound } \\
\text { effect through } \\
\text { extending life of } \\
\text { inefficient } \\
\text { products }\end{array}$ & $\begin{array}{l}\text { Minimal } \\
\text { rebound } \\
\text { effects }\end{array}$ & $\begin{array}{l}\text { Potential rebound } \\
\text { from increased use } \\
\text { of electronic } \\
\text { products }\end{array}$ & $\begin{array}{l}\text { Potential rebound } \\
\text { from increased } \\
\text { consumption and } \\
\text { transport emissions }\end{array}$ & $\begin{array}{l}\text { Potential rebound } \\
\text { at } \\
\text { production/EoL } \\
\text { for substitute } \\
\text { materials }\end{array}$ \\
\hline \multicolumn{9}{|l|}{ Material barriers } \\
\hline $\begin{array}{l}\text { Complex design/chemistries } \\
\text { of materials and products }\end{array}$ & & & $x$ & $x$ & $\mathrm{x}$ & $x$ & & $\mathrm{x}$ \\
\hline Technological obsolescence & $\mathrm{x}$ & & $\mathrm{x}$ & & $x$ & & & \\
\hline Degradation/dissipation in use & $\mathrm{x}$ & $x$ & $\mathrm{x}$ & $\mathrm{x}$ & $x$ & & & \\
\hline $\begin{array}{l}\text { Limits of } \\
\text { shareability/serviceability }\end{array}$ & & $\mathrm{x}$ & & & & $\mathrm{x}$ & $x$ & \\
\hline \multicolumn{9}{|l|}{ Economic barriers } \\
\hline $\begin{array}{l}\text { Businesses protecting market } \\
\text { share }\end{array}$ & $\mathrm{x}$ & & $\mathrm{x}$ & $\mathrm{x}$ & $x$ & & & \\
\hline $\begin{array}{l}\text { Inexpensive products/high } \\
\text { labour costs in Australia }\end{array}$ & & & $x$ & $\mathrm{x}$ & $x$ & & & \\
\hline $\begin{array}{l}\text { Shifting of profits in supply } \\
\text { chain }\end{array}$ & $\mathrm{x}$ & $\mathrm{x}$ & $\mathrm{x}$ & $\mathrm{x}$ & & $\mathrm{x}$ & $\mathrm{x}$ & \\
\hline
\end{tabular}


Table 3. Cont

\begin{tabular}{|c|c|c|c|c|c|c|c|c|}
\hline & \multicolumn{3}{|c|}{ Product Longevity } & \multirow[t]{2}{*}{ Remanufacturing } & \multirow[t]{2}{*}{$\begin{array}{l}\text { Component } \\
\text { Reuse }\end{array}$} & \multicolumn{3}{|c|}{ Using Less Material for the Same Product or Service } \\
\hline & Life Extension & Intensity of Use & $\begin{array}{l}\text { Repair and } \\
\text { Resale }\end{array}$ & & & Digitisation & Servicisation & Lightweighting \\
\hline \multicolumn{9}{|l|}{ Social barriers } \\
\hline $\begin{array}{l}\text { Consumer desire for new } \\
\text { products }\end{array}$ & $x$ & & $x$ & $\mathrm{x}$ & $x$ & & & \\
\hline Hoarding EoL products & & & $x$ & $x$ & $x$ & & & \\
\hline $\begin{array}{l}\text { Lack of acceptance of shared, } \\
\text { virtual or service products }\end{array}$ & & $x$ & & & & & $x$ & \\
\hline
\end{tabular}




\subsubsection{Major Household Appliances}

Major household appliances such as refrigerators, washing machines, and televisions, can be categorised as "workhorses" (see Cox et al. [27]), where consumers have the greatest expectation for longevity. Therefore, strategies to extend product lifetimes and repair products are likely to be most effective and acceptable, compared to the challenges faced in disassembly for recycling and component reuse. Servicisation and intensity of use strategies are also possible to replace individual ownership of a limited set of appliances, such as washing machines, dryers, tools, and gardening equipment. However, laundry services in Australia are declining, and sharing of tools and equipment through tool libraries and peer-to-peer rental platforms are relatively uncommon at present. If household products are also considered durable and have slow rates of technological or design development with new models, then there is potential for remanufacturing and component reuse to be successful strategies. However, so far, this strategy has been limited to very few products (such as refurbished blenders) that are initially expensive.

\subsubsection{Personal Electronics}

Personal electronic items have potentially large gains to be made in material efficiency, but have the least number of suitable strategies and face the largest barriers to implementation. The majority of these goods are not durable and have short product lifespans, whether due to technological obsolescence or the decision of consumers to replace them before their end of life. This presents a strong argument for extending the product life and adapting the design of products to allow easier upgrades, in addition to repair and reuse. However, repair and reuse may be difficult recognising that repair services in Australia can be limited by high labour costs relative to purchasing new devices. Currently, electronics collected for reuse are exported to overseas resale markets, where there is no oversight to ensure responsible management at the end of life. Remanufacturing and component reuse are currently very limited; however, there is not likely to be a large opportunity for these strategies without significant design changes to the products, due to their technological complexity and poor durability. Strategies of increasing intensity of use are mostly unsuitable due to the personal nature and frequency of use of these products. However, there is the potential for servicisation business models, such as leasing mobile phones and computers, where retailers retain ownership of the products and can facilitate the return of products at end of their first life for resale, remanufacturing, or recycling.

\subsection{Summary of Barriers}

The implementation of the material efficiency strategies is limited by major material barriers including: complex design; technological obsolescence; degradation or dissipation in use; the availability of spare parts; and the shareability or serviceability of products. Material efficiency strategies also face significant economic barriers. The majority of these strategies are not necessarily aligned with cost savings and/or new value opportunities for businesses. The exception to this may be lightweighting and component reuse, where there can be a clear economic case for manufacturers to undertake the effort. The high cost of labour and low cost of products is a barrier for labour-intensive strategies, in particular repair and resale, remanufacturing, and component reuse. For strategies that influence patterns of consumption, the location of value in the supply chain may shift with the introduction of these strategies. For example, there is little incentive for a product manufacturer to extend product life when profit is based on volume of sales, but new value opportunities may emerge for a business engaged in repairing or remanufacturing the product [107].

Certain business practices, such as promoting new trends and constantly developing new technologies to supersede existing products and differentiate products from those of competitors, directly engage with the practices of consumers and create social barriers to material efficiency strategies. Consumers may desire new or superior products, which is a barrier to the success of product life extension if consumers replace a product before needed, and for repair or remanufacturing strategies if 
there is no consumer demand for these products. Consumers may also hoard products at the end of life, which prevents their ability to be returned to the economy for repair, reuse, or remanufacturing. New business models have the potential to shift both business and consumer practices. Where businesses provide a service or product leasing, their incentives begin to align with the strategies of product longevity and repair. Businesses retaining ownership of goods create a mechanism to ensure that products are collected and not hoarded by consumers [40].

\subsection{Potential Role for Government and Industry}

The material, economic, and social barriers to implementation of these strategies highlight the importance of new policy and new business models. This is supported by a growing body of literature that characterises new circular economy business models as potential vehicles for changing consumption patterns [108]. The current policy focus in Australia is not sufficiently nuanced to drive many of the strategies discussed in this paper. Current approaches-the national Product Stewardship Act (2011), state landfill levies, and proposed e-waste landfill bans (for Victoria) — provide an important price signal to promote recycling for metal-containing products, and in some cases, provide revenue to support recycling infrastructure development [109]. However, they do not support the fundamental socio-technical changes in product design and use required to support material efficiency strategies of product longevity, remanufacturing, and component reuse [110]. As many of these strategies are limited by product quality (including durability, degradation, and technical obsolescence), there is a need for policy that obliges manufactures to adhere to product quality standards, including for the longevity and recyclability of goods. Other policy interventions include procurement policies that could help promote design for product longevity and grow new markets for reused, repaired, or remanufactured equipment. For products that are not manufactured in Australia, as is the case for most electrical and electronic goods, there is potential for distributors and retailers to collaborate with and support overseas producers to develop and adhere to responsible product and supply chain standards, which can enable longer product lifetimes and take-back to facilitate repair and reuse.

\section{Conclusions}

The implementation of material efficiency strategies for metal-containing consumer products represents an opportunity to reduce total resource demand and promote the transition to a circular economy for metals. In this paper, we evaluated the current implementation of four material efficiency strategies: product longevity (including life extension, intensity of use, repair and resale), remanufacturing, component reuse, and using less material for the same product or service (including digitisation, servicisation, and lightweighting). We then reviewed the material, economic, and social barriers and identified opportunities to expand these strategies more broadly beyond their current implementation.

Considering the strategies for each product type, many of the material efficiency strategies are already broadly applied for mobility, but there is a large opportunity to further increase intensity of use and servicise vehicle use. For household appliances, life extension and repair and resale have the greatest potential for further application; in addition there is an opportunity to increase intensity of use for mobile and infrequently used goods. Personal electronics had the lowest number of strategies currently implemented and face the highest number of barriers, which suggests key opportunities for material efficiency through product life extension and repair and reuse.

Product longevity strategies emerged as the most significant opportunity for material efficiency of metal-containing products in Australia (considering applicability to product types, material efficiency benefits, and barriers). Across the three product categories evaluated in this study (mobility, household appliances, and personal electronics), the product longevity sub-strategies: life extension and repair and resale had the broadest applicability and potential for material efficiency benefits, particularly for products with high environmental impacts in production. However, these strategies also face numerous barriers. The intensity of use sub-strategy faced fewer barriers; however, it is less widely applicable and may be subject to more rebound impacts. Remanufacturing and component reuse have 
limited applicability as they are only suitable for durable product types and standardized components. At the same time, they face considerable barriers, in particular with the decline of manufacturing in Australia. Strategies focused on using less material for the same product or service (digitisation, servicisation, and lightweighting) appeared to have fewer barriers; however, they also have less opportunity to expand implementation as they are only suitable for specific types of products. In addition, they appear to have more potential for rebound effects, and consequently the material efficiency benefits are less certain.

In order to support further implementation of product longevity strategies in Australia, policy and regulation will be needed to incentivise a shift in business models and to encourage a change in consumer practices. Existing policies and programs in Australia will need to expand their focus beyond recycling, to material efficiency strategies that have the potential to slow and narrow material loops and enable a circular economy. To overcome the barriers to product longevity strategies (including durability, degradation, and technical obsolescence), there is a need for policy targeting upstream actors with the capacity to improve product quality. Given that many products are not manufactured in Australia, procurement policies and product stewardship are likely to be important policy instruments.

Acknowledgments: This research was funded by the Wealth from Waste Cluster, a research collaboration between the Australian Commonwealth Scientific and Industrial Research Organisation (CSIRO), the University of Technology Sydney (UTS), the University of Queensland, Swinburne University of Technology, Monash University, and Yale University. The authors gratefully acknowledge the contribution from the CSIRO Flagship Collaboration Fund. The Cluster is part of the Minerals Resources Flagship and is supported by the Manufacturing Flagship.

Author Contributions: N.F., E.D. and M.R. analyzed and wrote major sections of the paper. S.S., R.L., M.A.R., G.C. and D.G. contributed to the framing of the paper and writing of the case study examples.

Conflicts of Interest: The authors declare no conflict of interest. The funders had no role in the design of the study; in the collection, analyses, or interpretation of data; in the writing of the manuscript; or in the decision to publish the results.

\section{References}

1. Hertwich, E.G.; Gibon, T.; Bouman, E.A.; Arvesen, A.; Suh, S.; Heath, G.A.; Bergesen, J.D.; Ramirez, A.; Vega, M.I.; Shi, L. Integrated life-cycle assessment of electricity-supply scenarios confirms global environmental benefit of low-carbon technologies. Proc. Natl. Acad. Sci. USA 2015, 112, 6277-6282. [CrossRef] [PubMed]

2. Ali, S.H.; Giurco, D.; Arndt, N.; Nickless, E.; Brown, G.; Demetriades, A.; Durrheim, R.; Enriquez, M.A.; Kinnaird, J.; Littleboy, A.; et al. Corrigendum: Mineral supply for sustainable development requires resource governance. Nature 2017, 547, 246. [CrossRef] [PubMed]

3. International Council on Mining \& Metals (ICMM). Mining and Metals and the Circular Economy; ICMM: London, UK, 2017.

4. Geissdoerfer, M.; Savaget, P.; Bocken, N.M.P.; Hultink, E.J. The Circular Economy-A new sustainability paradigm? J. Clean. Prod. 2017, 143, 757-768. [CrossRef]

5. Stahel, W. The service economy: "wealth without resource consumption"? Philos. Trans. R. Soc. A Math. Phys. Eng. Sci. 1997, 355, 1309-1319. [CrossRef]

6. Weizsäcker, E. von; Lovins, A.B.; Lovins, L.H. Factor Four: Doubling Wealth—Halving Resource Use; The New Report to the Club of Rome; Reprinted; Earthscan: London, UK, 1997; ISBN 1-85383-406-8.

7. McDonough, W.; Braungart, M. Cradle to Cradle: Remaking the Way We Make Things, 1st ed.; North Point Press: New York, NY, USA, 2002; ISBN 0-86547-587-3.

8. Allenby, B. The ontologies of industrial ecology? Prog. Ind. Ecol. Int. J. 2006, 3, 28-40. [CrossRef]

9. O'Rourke, D.; Connelly, L.; Koshland, C.P. Industrial ecology: A critical review. Int. J. Environ. Pollut. 1996, $6,89-112$.

10. Ellen Macarthur Foundation. Towards the Circular Economy: Economic and Business Rationale for an Accelerated Transition; Ellen Macarthur Foundation: Cowes, UK, 2013; Volume 1.

11. Ellen Macarthur Foundation; McKinsey Center for Business and Environment; Deutsche Post Foundation. Growth Within: A Circular Economy Vision for a Competitive Europe; Ellen Macarthur Foundation: Cowes, UK, 2015. 
12. WEF. Towards the Circular Economy: Accelerating the Scale-Up Across Global Supply Chains; World Economic Forum: Cologny, Switzerland, 2014.

13. Graedel, T.E.; Allwood, J.; Birat, J.-P.; Buchert, M.; Hagelüken, C.; Reck, B.K.; Sibley, S.F.; Sonnemann, G.; United Nations Environment Programme; Working Group on the Global Metal Flows. Recycling Rates of Metals: A Status Report; United Nations Environment Programme: Nairobi, Kenya, 2011; ISBN 978-92-807-3161-3.

14. Reuter, M.; Hudson, C.; Van Schaik, A.; Heiskanen, K.; Meskers, C.; Hagelüken, C. Metal Recycling: Opportunities, Limits, Infrastructure; A Report of the Working Group on the Global Metal Flows to the International Resource Panel; UNEP (United Nations Environment Programme): Nairobi, Kenya, 2013.

15. Golev, A.; Corder, G. Typology of Options for Metal Recycling: Australia's Perspective. Resources $2015,5,1$. [CrossRef]

16. Allwood, J.M. Squaring the Circular Economy. In Handbook of Recycling: State of the Art for Practitioners, Analysts, and Scientistis; Worrell, E., Reuter, M., Eds.; Elsevier: Amsterdam, The Netherlands, 2014; pp. 445-447, ISBN 978-0-12-396459-5.

17. Azapagic, A. Developing a framework for sustainable development indicators for the mining and minerals industry. J. Clean. Prod. 2004, 12, 639-662. [CrossRef]

18. Norgate, T.; Haque, N. Energy and greenhouse gas impacts of mining and mineral processing operations. J. Clean. Prod. 2010, 18, 266-274. [CrossRef]

19. Corder, G.D.; Golev, A.; Giurco, D. "Wealth from metal waste": Translating global knowledge on industrial ecology to metals recycling in Australia. Miner. Eng. 2015, 76, 2-9. [CrossRef]

20. UNEP (Ed.) Metal Recycling: Opportunities, Limits, Infrastructure: This Is Report $2 b$ of the Global Metal Flows Working Group of the International Resource Panel of UNEP; United Nations Environment Programme: Nairobi, Kenya, 2013; ISBN 978-92-807-3267-2.

21. Florin, N.; Madden, B.; Sharpe, S.; Benn, S.; Agarwal, R.; Perey, R.; Giurco, D. Shifting Business Models for a Circular Economy: Metals Management for Multi-Product-Use Cycles; University of Technology Sydney: Sydney, Australia, 2015.

22. Jericho, G. The Mining Investment Boom Is Over, So Where to Now? The Guardian, 29 August 2014. Available online: https: / www.theguardian.com/business / grogonomics/2014/aug/29/mining-investment-boomis-over-so-where-to-now (accessed on 22 January 2018).

23. Allwood, J.M.; Ashby, M.F.; Gutowski, T.G.; Worrell, E. Material efficiency: A white paper. Resour. Conserv. Recycl. 2011, 55, 362-381. [CrossRef]

24. Allwood, J.M.; Cullen, J. Sustainable Materials: With Both Eyes Open; UIT Cambridge: Cambridge, UK, 2012.

25. Ciacci, L.; Reck, B.K.; Nassar, N.T.; Graedel, T.E. Lost by Design. Environ. Sci. Technol. 2015, 49, $9443-9451$. [CrossRef] [PubMed]

26. Grimes, S.; Donaldson, J.; Gomex, G.C. Report on the Environmental Benefits of Recycling; Bureau of International Recycling (BIR): Brussels, Belgium, 2008.

27. Cox, J.; Griffith, S.; Giorgi, S.; King, G. Consumer understanding of product lifetimes. Resour. Conserv. Recycl. 2013, 79, 21-29. [CrossRef]

28. ACCC Consumer Guarantees. Available online: https://www.accc.gov.au/consumers/consumer-rightsguarantees/consumer-guarantees (accessed on 19 January 2018).

29. Ladd, M. Holden and Australia's History of Car Manufacturing. Available online: http://www.abc. net.au/news/2017-10-08/holden-closure-australia-history-car-manufacturing/9015562 (accessed on 19 January 2018).

30. Pearce, M. End of the Line for Australian Fridge Production. Available online: http://www.abc.net.au/ news / 2016-04-11/last-australian-made-fridge-is-end-of-the-line-for-manufacturer/7316682 (accessed on 19 January 2018).

31. Riedy, C.; Milne, G. Your Home-Appliances. Available online: http://www.yourhome.gov.au/energy / appliances (accessed on 19 January 2018).

32. Australian Government Australian Design Rules. Available online: https://infrastructure.gov.au/roads/ motor/design/index.aspx (accessed on 19 January 2018). 
33. Apple Inc. iPhone 3G Environmental Report 2009; Apple Inc.: Cupertino, CA, USA, 2009.

34. Apple Inc. iPhone 6s Environmental Report 2015; Apple Inc.: Cupertino, CA, USA, 2015.

35. AMTA. 2015-2016 Mobile Muster Annual Report 2016; Australian Mobile Telecommunications Association: Canberra, Australia, 2016.

36. Fairphone Fairphone-The Modular Phone That's Built to Last. Available online: https://www.fairphone. $\mathrm{com} / \mathrm{en} /$ (accessed on 19 Jan 2018).

37. Botsman, R.; Rogers, R. What's Mine Is Yours: The Rise of Collaborative Consumption; Harper Collins: New York, NY, USA, 2010.

38. Owyang, J.; Samuel, A.; Grenville, A. Sharing Is the New Buying: How to Win in the Collaborative Economy; Vision Critical: Vancouver, BC, Canada, 2014.

39. Mont, O. Clarifying the concept of product-Service system. J. Clean. Prod. 2002, 10, 237-245. [CrossRef]

40. Tukker, A. Product services for a resource-efficient and circular economy-A review. J. Clean. Prod. 2015, 97, 76-91. [CrossRef]

41. SGS Economics \& Planning. Benefit-Cost Analysis of Car Share within the City of Sydney: Final Report; SGS Economics \& Planning: Sydney, Australia, 2012.

42. Martin, E.; Shaheen, S. The impact of carsharing on household vehicle ownership. Access 2011, 38, $22-27$.

43. Chan, N.D.; Shaheen, S.A. Ridesharing in North America: Past, Present, and Future. Transp. Rev. 2012, 32, 93-112. [CrossRef]

44. CoSeats Rideshare in Australia. Available online: https://www.coseats.com (accessed on 24 January 2018).

45. Shareurride Rideshare Australia-Free Carpooling Sydney, Melbourne, Brisbane. Available online: http: / / www.shareurride.com.au/ (accessed on 24 January 2018).

46. Galloway, A. The New Features Coming to Uber. Available online: http://www.heraldsun.com. $\mathrm{au} /$ news/victoria/ubers-new-app-features-include-intercom-pickup-location-changes/news-story / 53a1da98018bcff802174c976d40127d (accessed on 25 January 2018).

47. Furuhata, M.; Dessouky, M.; Ordóñez, F.; Brunet, M.-E.; Wang, X.; Koenig, S. Ridesharing: The state-of-the-art and future directions. Transp. Res. Part BMethodol. 2013, 57, 28-46. [CrossRef]

48. Siddiqi, Z.; Buliung, R. Dynamic ridesharing and information and communications technology: Past, present and future prospects. Transp. Plan. Technol. 2013, 36, 479-498. [CrossRef]

49. Bromhead, N. Going Dockless: Lookout Reddy Go, Ofo \& OBike ... Mobike Is Here. Available online: http:/ / www.bicyclingaustralia.com.au/news/going-dockless-lookout-reddy-go-ofo-and-obikemobike-is-here (accessed on 19 January 2018).

50. Yoo, T. Dockless bicycles are trashing Sydney and Melbourne streets ... and rivers. Business Insider Australia. 27 September 2017. Available online: https:/ / www.businessinsider.com.au/dockless-bicycles-are-trashingsydney-and-melbourne-streets-and-rivers-2017-9 (accessed on 22 January 2018).

51. Haas, B. Chinese Bike Share Graveyard a Monument to Industry's "Arrogance". Available online: http:/ / www.theguardian.com/uk-news/2017/nov/25/chinas-bike-share-graveyard-a-monumentto-industrys-arrogance (accessed on 19 January 2018).

52. Allday, A. IBISWorld Industry Report L6639 Furniture, Appliance and Equipment Rental in Australia; IBISWorld: Melbourne, Australia, 2017.

53. Retamal, M.; Schandl, H. Dirty laundry in Manila: Comparing resource consumption practices for individual and shared laundering. J. Ind. Ecol. 2017. [CrossRef]

54. Retamal, M. Characterizing collaborative consumption in Southeast Asian cities: Exploring the possibilities for "lifestyle leapfrogging". 2018, submitted.

55. Brunswick Tool Library Brunswick Tool Library, Inc. Available online: http:/ /brunswicktoollibrary.org/ php/index.php (accessed on 24 January 2018).

56. Blue Mountains Economic Enterprise Toolo-Blue Mountains Tool Library. MTNS MADE, 2018. Available online: https: / mtnsmade.com.au/listing/8-froma-court-katoomba-nsw-2780-toolo-blue-mountains-toollibrary/ (accessed on 22 January 2018).

57. Kool, G. Tool Libraries in Australia; University of New South Wales: Sydney, Australia, 2003.

58. ToolMates How Its Work. Available online: https://toolmateshire.com.au/how-its-work.html (accessed on 24 January 2018). 
59. OpenShed Put Your Stuff to Work. Available online: https://www.openshed.com.au/ (accessed on 24 January 2018).

60. Behrendt, S.; Behr, F. Oko-Rent im Bereich Heimwerken Baueigenleistungen und Gartenpflege; Institut für Zunftsstudien und Technologiebewertung (IZT): Berlin, Germany, 2000.

61. BMBF. BMBF-Verbundprojekt 'Oko-Effiziente Dienstleistungen als Strat- Egischer Wettbewerbesfaktor zur Entwicklung Einer Nachhaltiger Wirtschaft'. Endbericht.; Wuppertal Institut: Wuppertal, Germany, 1998.

62. Haapala, K.R.; Brown, K.L.; Sutherland, J.W. A life cycle environmental and economic comparison of clothes washing product-service systems. In Transactions of the North American Manufacturing Research Institution of SME; SME: Dearborn, MI, USA, 2008; Volume 36, pp. 333-340.

63. Komoto, H.; Tomiyama, T.; Nagel, M.; Silvester, S.; Brezet, H. Life Cycle Simulation for Analyzing Product Service Systems; Union of EcoDesigners: Tokyo, Japan, 2005.

64. Retamal, M. Product-service systems in Southeast Asia: Business practices and factors influencing environmental sustainability. J. Clean. Prod. 2017, 143, 894-903. [CrossRef]

65. IBISWorld. Motor Vehicle Engine and Parts Repair and Maintenance in Australia; IBISWorld: Melbourne, Australia, 2018.

66. IBISWorld. Bicycle Retailing and Repair in Australia; IBISWorld: Melbourne, Australia, 2017.

67. IBISWorld. Domestic Appliance Repair and Maintenance in Australia; IBISWorld: Melbourne, Australia, 2017.

68. IBISWorld. Computer and Electronic Equipment Repair in Australia; IBISWorld: Melbourne, Australia, 2017.

69. Baldé, C.P.; Wang, F.; Kuehr, R.; Huisman, J. The Global E-Waste Monitor 2014: Quantities, Flows and Resources; United Nations University: Bonn, Germany, 2015.

70. Maitre-Ekern, E.; Dalhammar, C. Regulating Planned Obsolescence: A Review of Legal Approaches to Increase Product Durability and Reparability in Europe. Rev. Eur. Comp. Int. Environ. Law 2016, 25, 378-394. [CrossRef]

71. ABS Population Clock. Available online: http://www.abs.gov.au/ausstats/abs@.nsf/Web+Pages/ Population+Clock?opendocument (accessed on 18 January 2018).

72. Lane, R.; Gumley, W.; Santos, D. Mapping, Characterising and Evaluating Collection Systems and Organisations: Draft Final Report; Monash University: Melbourne, Australia, 2015.

73. Lane, R.; Gumley, W. What role for the social enterprises in the circular economy? In Unmaking Waste; Crocker, R., Ed.; Springer: Berlin, Germany, 2017.

74. A\&B Automotive: A \& B Automatic Transmission Service, Repairs \& Remanufacturing. 2013. Available online: https: / /abautomatics.com.au/ (accessed on 22 January 2018).

75. ABS Quality \& Remanufactured Parts. Available online: https://www.absauto.com.au/parts/quality-newremanufactured-parts (accessed on 23 January 2018).

76. Auto Trans Australia Auto Trans Australia. Available online: http://autotransaustralia.com.au/ (accessed on 23 January 2018).

77. FluidDrive Fluid Drive-Better than New. Available online: http://fluiddrive.com.au/ (accessed on 23 January 2018).

78. IM Group Injectronics: Remanufactured Automotive Electronic Components. Available online: http://www. injectronics.com.au/ (accessed on 23 January 2018).

79. Wholesale Automatic Transmissions Re-Manufactured and Changeover Automatic Transmissions. Available online: https:/ / automatictransmission.com.au/re-manufactured-changeover-automatic-transmissions / (accessed on 23 January 2018).

80. Apple Inc. Apple Certified Refurbished: Shop Refurbished Products. Available online: https://www.apple. com/au/shop/browse/home/specialdeals (accessed on 23 January 2018).

81. Dell Australia Dell Outlet Australia-Factory Refurbished Laptops And Computers. Available online: http:/ / www.dell.com/learn/au/en/audhs1/campaigns/dell-outlet-au (accessed on 23 January 2018).

82. KitchenAid Refurbished KitchenAid Products. Available online: https://kitchenaid.com.au/refurbishedproducts (accessed on 23 January 2018).

83. Cooper, D.R.; Gutowski, T.G. The Environmental Impacts of Reuse: A Review: The Environmental Impacts of Reuse: A Review. J. Ind. Ecol. 2017, 21, 38-56. [CrossRef] 
84. Gutowski, T.G.; Sahni, S.; Boustani, A.; Graves, S.C. Remanufacturing and Energy Savings. Environ. Sci. Technol. 2011, 45, 4540-4547. [CrossRef] [PubMed]

85. Kerr, W.; Ryan, C. Eco-efficiency gains from remanufacturing: A case study of photocopier remanufacturing at Fuji Xerox Australia. J. Clean. Prod. 2001, 9, 75-81. [CrossRef]

86. Hatcher, G.D.; Ijomah, W.L.; Windmill, J.F.C. Design for remanufacture: A literature review and future research needs. J. Clean. Prod. 2011, 19, 2004-2014. [CrossRef]

87. Hatcher, G.D.; Ijomah, W.L.; Windmill, J.F.C. A network model to assist 'design for remanufacture' integration into the design process. J. Clean. Prod. 2014, 64, 244-253. [CrossRef]

88. Östlin, J.; Sundin, E.; Björkman, M. Product life-cycle implications for remanufacturing strategies. J. Clean. Prod. 2009, 17, 999-1009. [CrossRef]

89. Jiménez-Parra, B.; Rubio, S.; Vicente-Molina, M.-A. Key drivers in the behavior of potential consumers of remanufactured products: A study on laptops in Spain. J. Clean. Prod. 2014, 85, 488-496. [CrossRef]

90. Benn, S.; Dunphy, D. Fuji Xerox Australia Eco Manufacturing Centre: A case study in strategic sustainability. Innov. Manag. Policy Pract. 2004, 6, 258-268. [CrossRef]

91. Klausner, M. Reuse of electric motors in consumer products: Design and analysis of an electronic data log. J. Ind. Ecol. 1998, 2, 89-102. [CrossRef]

92. Cooper, D.R.; Allwood, J.M. Reusing Steel and Aluminum Components at End of Product Life. Environ. Sci. Technol. 2012. [CrossRef] [PubMed]

93. Crowther, P. Design for disassembly-themes and principles. BDP Environ. Des. Guide 2005, 2005, 1-7.

94. Planet Ark Whitegoods. Available online: http://recyclingnearyou.com.au/whitegoods/ (accessed on 22 January 2018).

95. ABS Electronic and Electrical Waste: 4602.0.55.005 Waste Account, Australia, Experimental Estimates, 2013. Available online: http:/ / www.abs.gov.au/ausstats/abs@.nsf/Products/4602.0.55.005 2013 Main+ Features Electronic+and+Electrical+Waste?OpenDocument (accessed on 22 January 2018).

96. Wright Corporate Strategy; Rawtec. A Study of Australia's Current and Future E-Waste Recycling Infrastructure Capacity and Needs; Department of Sustainability, Environment, Water, Population and Communities: Canberra, Australia, 2010.

97. Allan, P. End-of-Life Motor Vehicles: Market Snapshot 2007; Hyder Consulting for Sustainability Victoria: Melbourne, Australia, 2007.

98. The Climate Group. SMART 2020: Enabling the Low Carbon Economy in the Information Age; Global eSustainability Initiative (GeSI): Brussels, Belgium, 2008.

99. McKinsey. Digital Australia: Seizing the Opportunity from the Fourth Industrial Revolution; McKinsey: New York, NY, USA, 2017.

100. Leone, C.; Genna, S.; Caggiano, A. Resource efficient low power laser cleaning of compact discs for material reuse by polycarbonate recovery. CIRP J. Manuf. Sci. Technol. 2015, 9, 39-50. [CrossRef]

101. Kowalkiewicz, M.; Rosemannn, M.; Dootson, P. Retail 5.0: Check-Out the Future; QUT-PWC Chair in Digital Economy: Brisbane, Australia, 2017.

102. Allday, A. IBISWorld Industry Report $S 9531$ Laundry and Dry-Cleaning Services in Australia; IBISWorld: Los Angeles, CA, USA, 2017.

103. Cascio, J. Dematerialization: The Growth of Atomically Precise Manufacturing; Institute for the Future: Palo Alto, CA, USA, 2012.

104. Rucks, G. Lightweighting a Key To DOE's EV Everywhere Grand Challenge—Rocky Mountain Institute. Available online: https://rmi.org/news/blog_lightweighting_key_does_ev_everywhere_grand_challenge/ (accessed on 23 January 2018).

105. Carruth, M.A.; Allwood, J.M.; Moynihan, M.C. The technical potential for reducing metal requirements through lightweight product design. Resour. Conserv. Recycl. 2011, 57, 48-60. [CrossRef]

106. Delogu, M.; Zanchi, L.; Dattilo, C.A.; Pierini, M. Innovative composites and hybrid materials for electric vehicles lightweight design in a sustainability perspective. Mater. Today Commun. 2017, 13, 192-209. [CrossRef]

107. Roos, G. Business Model Innovation to Create and Capture Resource Value in Future Circular Material Chains. Resources 2014, 3, 248-274. [CrossRef] 
108. Bocken, N.M.P.; Short, S.W.; Rana, P.; Evans, S. A literature and practice review to develop sustainable business model archetypes. J. Clean. Prod. 2014, 65, 42-56. [CrossRef]

109. NSW EPA. Waste Less, Recycle More; NSW Environment Protection Agency: Sydney, Australia, 2016.

110. Gumley, W. An Analysis of Regulatory Strategies for Recycling and Re-Use of Metals in Australia. Resources 2014, 3, 395-415. [CrossRef] 